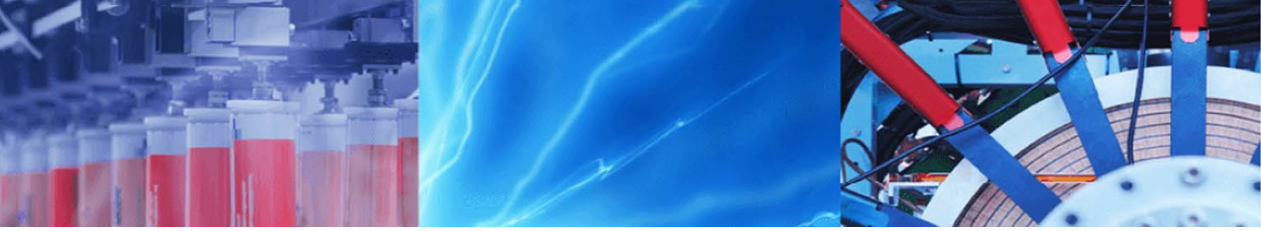

Research Article

\title{
Performance of eggshells powder as an adsorbent for adsorption of hexavalent chromium and cadmium from wastewater
}

\author{
Olubunmi G. Abatan ${ }^{1}$ - Peter A. Alaba ${ }^{2}$ (D) Babalola A. Oni ${ }^{1} \cdot$ Kelvin Akpojevwe ${ }^{1}$ - Vincent Efeovbokhan ${ }^{1}$. \\ Faisal Abnisa ${ }^{3}$
}

Received: 5 July 2020 / Accepted: 9 November 2020 / Published online: 13 November 2020

(c) Springer Nature Switzerland AG 2020

\begin{abstract}
This study explores the kinetic and equilibrium performance of eggshell as an adsorbent for hexavalent chromium and cadmium ion removal from wastewater. The experimental removal of the two metal ions was performed batch-wise and the influence of variables like initial metal loading, $\mathrm{pH}$, contact time, and adsorbent dose. Fourier-transform infrared spectroscopy spectra reveals that chromium and cadmium ion interact with carbonyl, carboxylic, hydroxyl functional groups in eggshell. The best $\mathrm{pH}$ is 6 , and the adsorption capacity improves with increasing initial concentration of adsorbate, $\mathrm{pH}$, contact time and adsorbent dosage for chromium and cadmium ion. Pseudo-second-order kinetics is the most suitable model for the removal of chromium and cadmium ion, while the equilibrium agrees with Freundlich isotherms. These outcomes reveal that eggshell is a promising cheap adsorbent for adsorption of toxic heavy metals like chromium and cadmium ion from aqueous solution.
\end{abstract}

Keywords Eggshell · Adsorption · Kinetics · Hexavalent chromium · Divalent cadmium

\section{Introduction}

Pollution of natural water with toxic heavy metals is expanding step by step as a result of industrial development and growth [3]. This incident has become a striking worldwide concern since it poses a health risk to human life [9]. The existence of these toxic heavy metals is noticeable in fluid streams and soil because of social activities [11]. Human exploring produces waste, and these waste products are treated, disposed of, gathered and discarded, which can present hazards to nature and overall well-being [5]. Because of the alarming rate of the issue of heavy metal contamination, the investigation into new and modest strategies for metal expulsion has expanded as of late [8].
Hexavalent chromium $(\mathrm{Cr}(\mathrm{VI}))$ and cadmium $(\mathrm{Cd}(\mathrm{II}))$ belong to the most toxic of heavy metals and are extremely hazardous to human health because its prolonged exposure can cause endocrine disorders, carcinogenesis, renal dysfunction, mutagenesis and bone fracture $[10,29]$. Chromium is aboundantly used in electroplating metallurgy, and leather tanning, other industries, leading to the release of aqueous chromium (in stable forms trivalent chromium $(\mathrm{Cr}(\mathrm{III}))$ and $\mathrm{Cr}(\mathrm{VI}))$ to the environment [29]. Hexavalent chromium seldom occur naturally, quite soluble in aqueous systems and often find its way to the groundwater [24]. The major source of cadmium pollution includes silver-cadmium, plastics, electroplating, paint pigments, and smelter operations and nickel-cadmium battery industry [14]. The release of wastewater containing $\mathrm{Cd}(\mathrm{II})$ pollutes both the soil and water bodies.

$\triangle$ Faisal Abnisa, adeniyipee@live.com; fta@kau.edu.sa | 'Department of Chemical Engineering, Covenant University, Ota 112212, Nigeria. ${ }^{2}$ Department of Chemical Engineering, Faculty of Engineering, University of Malaya, 50603 Kuala Lumpur, Malaysia. ${ }^{3}$ Department of Chemical and Materials Engineering, King Abdulaziz University, Jeddah, Saudi Arabia. 
Techniques like precipitation buoyancy, filtration, sedimentation, particle exchange, dissolvable removal, electrolytic methods, layer processing, natural method, and substance reaction have been explored [2, 32, 33]. Each approach applies its advantages and flaws. Therefore, it is essential to search for prudent and convincing methods for separation of substantial metals from aqueous solution [34]. Remediation procedures must be intended for high or great removal of impurities while downplaying costs [4]. Since most common approaches are neither practical nor conservative, a better separation method is needed for removal of heavy metal at low-cost. Bio deportation may contribute to the achievement organic expulsion can help to achieve this objective [15].

One of the approaches used for removal of contaminants from wastewater equivalent to heavy metals is adsorption [39]. Adsorption is a physicochemical technique extensively applied for removal of heavy metal since it does not require elevated operation temperature and it can removed several materials all at once [29]. Metals were expelled by adsorption on multiple products, e.g. activated coal, agricultural waste, green vegetation, minerals, etc. [42]. The adsorbent should be accessible in massive amounts, abundant in nature, readily reusability and cost-effective. Prominent of the adsorbent applied earlier is activated carbon, which exhibits remarkable performance for heavy metal removal, but activated carbon is not easy to regenerate, and expensive to maintain, leading to its narrow application [29].

Agricultural goods may be used as heavy metal sorbents particular to individual metal particles. The rural side effects of metal particle adsorption may include metal collaboration or coordination with the introduction of helpful collections in protein, lipids and sugars on cell dividers [1]. The ever-increasing global consumption of hen eggs is leading to a proliferation of large quantity of eggshells. Disposal of eggshell is a major challenge in the poultry and bakery units of the food industry. In the search for versatile, readily available, non-toxic, and cost-effective resources as potential adsorbent to remove hazardous chemicals from water, eggshells have emerged as a suitable candidate [30]. Studies have shown that eggshell is promising for removal of heavy metals, organic dyes, Polycyclic aromatic hydrocarbons (PAHs), pharmaceutics (morphine) $[22,30]$. Substantially toxic heavy metals like arsenic, manganese, lead, copper, cadmium, chromium, and mercury could be removed using eggshells. Eggshell contains $94 \%$ calcium carbonate, $1 \%$ calcium phosphate, $1 \%$ magnesium carbonate, and $4 \%$ organic matter by weight [6]. Eggshells are produced mainly as a by-product of the poultry industry, making it recommendable as adsorbents. Several researchers have used eggshells to remove heavy metals $[7,17]$. Elabbas et al. [17] explored the use of crushed hen eggshells for removal of $\mathrm{Cr}(\mathrm{VI})$ ions from wastewater. They revealed that eggshells had a fairly high removal capacity in comparison with other adsorbents. Baláž et al. [10] investigated Cd(II) removal capacity of crushed eggshell in wastewater in a batch adsorption system. Park et al. [38] investigated the comparative removal of $\mathrm{Cr}$, and $\mathrm{Cd}$ from electroplating wastewaters but did not explore the adsorption kinetic and equilibrium.

This work aims to explore the comparative adsorptive performance of eggshell for $\mathrm{Cr}(\mathrm{VI})$ and ( $\mathrm{Cd}(\mathrm{II})$ ions, including the adsorption kinetic and equilibrium, for the first time. This venture will unravel the adsorption equilibrium using Langmuir and Freundlich isotherms. The adsorption kinetic will also be explored using pseudo-first-order and pseudo-second-order, and the influence of $\mathrm{pH}$, contact time, initial adsorbate loading, and adsorbent dose.

\section{Materials and methodology}

\subsection{Materials}

All chemical reagents used for this work were of analytical grade, high purity, and utilized with no further refinement. All the experiments were conducted with deionized water prepared in our laboratory at room temperature. Hydrochloric acid, sodium hydroxide, cadmium nitrate (AR grade) and potassium dichromate (AR grade) were bought from Sinopharm Chemical Reagent Co., Ltd. Chicken eggshells were obtained from the Covenant University cafeteria in Ogun state, Nigeria.

\subsection{Adsorbent preparation}

The chicken eggs were washed a couple of times with deionized water and boiled for $10 \mathrm{~min}$ to remove contaminated particles from it. For $3 \mathrm{~h}$, the eggshells were oven-dried at $150^{\circ} \mathrm{C}$ and left to cool to $25^{\circ} \mathrm{C}$ (ambient temperature). The dried samples were pulverized to 80-210 $\mu \mathrm{m}$ mesh size using a jaw crusher manufactured by Denver Product, Dagenham, U.K. The powdered eggshell was kept in an vacuum container for further use at room temperature.

\subsection{Characterization of adsorbent}

For the FT-IR analysis, adsorbent infrared spectra were obtained using Bruker Tensor $27 \mathrm{FT}-\mathrm{IR}$ at $4 \mathrm{~cm}^{-1}$ resolution in the range of $700-4000 \mathrm{~cm}^{-1}$. The sample was intimately mixed with $\mathrm{KBr}$. SEM images were generated using SEM, FEI Quanta $400 \mathrm{FE}-\mathrm{SEM}$ microscope, with an accelerator current of $20 \mathrm{~mA}$ and voltage of $20 \mathrm{kV}$. To excite the distinctive X-ray of the components stored in the sample, EDS analysis was 
conducted utilizing a concentrated electron beam operating on a tiny region of the sampled specimen.

\subsection{Batch adsorption studies}

The heavy metal removal experiments were carried out using batch adsorption. $5 \mathrm{~g}$ of the adsorbent was dispersed in $200 \mathrm{~mL}$ a solution containing $50 \mathrm{mg} / \mathrm{L}$ of hexavalent $\mathrm{Cr}(\mathrm{VI}) / \mathrm{Cd}(\mathrm{II})$ obtained by dissolving cadmium nitrate or potassium dichromate in distilled water. The aqueous solution was stirred (at $150 \mathrm{rpm}$ ) in a water bath shaker at ambient temperature. Afterward, the mixture was filtered, and the residual $\mathrm{Cd}(\mathrm{II})$ or $\mathrm{Cr}(\mathrm{VI})$ ions in the filtrate were observed using the Atomic Absorption Spectrometer (AAS). The quantity of $\mathrm{Cd}(\mathrm{II})$ or $\mathrm{Cr}(\mathrm{VI})$ removed at equilibrium $\left(\mathrm{q}_{\mathrm{e}}\right)$ was computed using the expression below:

$q=\frac{\left(C_{0}-C_{e}\right) V}{W}$

The removal efficiency was obtained as:

\% removal $=\frac{\left(C_{0}-C_{e}\right)}{C_{0}} \times 100$

where $q$ represents the quantity of metal ion removed per gram of adsorbent, $C_{0}(\mathrm{mg} / \mathrm{L})$ is the initial amount of metal ion loaded, $C_{e}(\mathrm{mg} / \mathrm{L})$ is the amount of metal ion at equilibrium, $W(\mathrm{~g})$ is the mass of adsorbent, and $V(\mathrm{~L})$ is the volume of the aqueous solution containing metal ions.

The percentage removal was observed at varying contact time for each adsorbate to obtain the equilibrium time. The experiment was repeated using different loading of the metal ion in the solutions $(50-200 \mathrm{mg} / \mathrm{L})$. The effect of $\mathrm{pH}$ (with the aid of $0.1 \mathrm{M} \mathrm{NaOH}$ and $0.1 \mathrm{M} \mathrm{HCl}$ solutions), dosage of adsorbent (5-25 g), contact time (30-150 $\mathrm{min}$ ) and initial adsorbate loading were investigated.

\subsection{Adsorption equilibrium}

\subsubsection{Langmuir isotherm model}

This model has a fundamental hypothesis that at a site on the surface of the sorbent with uniform energy level, dissemination of adsorption occurs. If the adsorbent fills all the vacant sites, there will be no room for further adsorption [1]. If this is the case, it means that the adsorption model is monolayer in nature. The following equation represents the linear shape of the Langmuir isotherm design cab:

$\frac{C_{e}}{q_{e}}=\frac{1}{K_{L}}+\frac{a_{L}}{K_{L}}\left(C_{e}\right)$ where $C_{e}$ is the balance temperature $(\mathrm{mg} / \mathrm{L}), q_{e}$ is the quantity of metal ion removed by the designated quantity of adsorbent $(\mathrm{mg} / \mathrm{g}) \cdot a_{L}(\mathrm{~L} / \mathrm{mg})$ and $K_{L}(\mathrm{~L} / \mathrm{g})$ are the constants of Langmuir isotherm. The linear charts were used to estimate the value of $K_{L}$ from the curve and the value of $a_{L}$ from the path, the linear charts acquired were used.

\subsubsection{Freundlich isotherm model}

This model appears to be a direct reverse of the Langmuir model, this model with a basic theory that adsorption happens on non-uniform power level dissemination heterogeneous locations. It is not of the monolayer type, unlike the Langmuir template [1].

With this equation, the Freundlich isotherm model's linear shape can be depicted:

$\ln q_{e}=\ln K_{F}+\frac{1}{n} \ln C_{e}$

where $\mathrm{K}_{\mathrm{F}}$ is the heterogeneity variable representing the bond distribution. As straight rows, a chart of $\ln \mathrm{q}_{\mathrm{e}}$ versus In $C_{e}$ was acquired. Constants $K_{F}$ and $1 / n$ were calculated from the curve and curve.

\subsection{Adsorption kinetics}

Adsorption rate estimation provides essential data for batch adsorption devices to be created. For choosing best operating parameters for large-scale batch methods, figures acquired on the kinetics of the solution uptake are essential [1]. Pseudo-first-order and pseudosecond-order kinetic equations used in the study were employed to investigate the kinetics of heavy metals adsorption and obtain the amount of absorbed metal ions. The Lagergren pseudo-first-order model is mainly written as:

$\ln \left(q_{e}-q_{t}\right)=\ln q_{e}+k_{1} t$

where $\mathrm{q}_{\mathrm{t}}$ and $\mathrm{q}_{\mathrm{e}}$ represent the timing, and equilibrium capacities for adsorption $(\mathrm{mg} / \mathrm{g})$ and $\mathrm{k}_{1}$ is the pseudo-firstorder adsorption constant ( $1 / \mathrm{min})$. At distinct levels, plots of $\ln \left(q_{e}-q_{t}\right)$ against $t$ are displayed. It is then possible to obtain $k_{1}$ and $q_{e}$ from the path and intercept.

For pseudo-second-order, the model is as follow:

$\frac{t}{q_{t}}=\frac{1}{k_{2} q e^{2}}+\frac{t}{q_{e}}$

From a graph of $t / q_{t}$ against $t$, linear charts are achieved from which $\mathrm{K}_{2}$ and $\mathrm{q}_{\mathrm{e}}$ could be computed using the curve and intercept. 


\section{Results and discussion}

\subsection{Characterization}

The surface morphology of the selected adsorbents as obtained using SEM is shown in Fig. 1. The figure highlights the SEM images obtained for the Eggshell samples before and after the removal of $\mathrm{Cr}(\mathrm{VI})$ and $\mathrm{Cd}(\mathrm{II})$. The SEM analysis also shows that the treatment of $\mathrm{Cr}(\mathrm{VI})$ and $\mathrm{Cd}$ (II) solutions affected the matrix of the eggshell structure. The SEM image of the eggshell sample before heavy metal adsorption shows non-adhesive appearance and agglomerates formation. Meanwhile, after adsorption, the samples show regular, adhesive appearance, could further remove $\mathrm{Cd}(\mathrm{II})$ and $\mathrm{Cr}(\mathrm{VI})$. However, there seems to be more adhesive appearance on the sample that adsorbed $\mathrm{Cd}(\mathrm{II})$ than that of $\mathrm{Cr}(\mathrm{VI})$ (Fig. 2).

The FT-IR spectrum (Fig. 3) of unloaded eggshell shows several distinct absorption bands showing the complicated nature of eggshells. The peaks in between $3634.01 \mathrm{~cm}^{-1}$ and $2337.8 \mathrm{~cm}^{-1}$ are traceable to the existence of hydroxyl functional group, and at $1805 \mathrm{~cm}^{-1}$, a strong $\mathrm{C}=0$ group. The peaks at 1635.69 and $1411.94 \mathrm{~cm}^{-1}$ represent the presence of medium $\mathrm{C}=\mathrm{C}$ and $\mathrm{C}=\mathrm{O}$ stretching vibration [1]. This result comforms with the result of [7] that reported the presence of carbonyl group around $1424 \mathrm{~cm}^{-1}$ wavelength. The bands at $871.87 \mathrm{~cm}^{-1}$ due to $\mathrm{C}=\mathrm{C}, 771.55 \mathrm{~cm}^{-1}$ and $702.11 \mathrm{~cm}^{-1}$ due to $\mathrm{C}-\mathrm{H}$ are typical of the in-plane and out-plane deformation modes in the presence of calcium carbonate [20]. This shows that eggshell mainly contains calcite.

Figure 3 also presents the FT-IR spectra of the eggshell samples after taken up $\mathrm{Cd}(\mathrm{II})$ and $\mathrm{Cr}(\mathrm{VI})$ to ascertain the functional groups that are accountable for metal ion removal. For the sample loaded with Cd (II), the spectra at $3749.74 \mathrm{~cm}^{-1}$ broaden with reduced intensity and shifted to lower wavenumber $\left(3626.29 \mathrm{~cm}^{-1}\right)$ after Cd (II) adsorption. For the sample loaded with $\mathrm{Cr}(\mathrm{VI})$ with that of the unloaded, it was observed that the band at $3749.74 \mathrm{~cm}^{-1}$ broaden and its intensity declined, and the band shift to lower wavenumber $\left(3649.44 \mathrm{~cm}^{-1}\right)$ after adsorption of $\mathrm{Cr}(\mathrm{VI})$. The observations reveal that the bands of $\mathrm{OH}$
Fig. 1 SEM image of a chicken eggshell before adsorption, $\mathbf{b}$ chicken eggshell after $\mathrm{Cd}(\mathrm{II})$ adsorption, c chicken eggshell after $\mathrm{Cr}(\mathrm{VI})$ adsorption
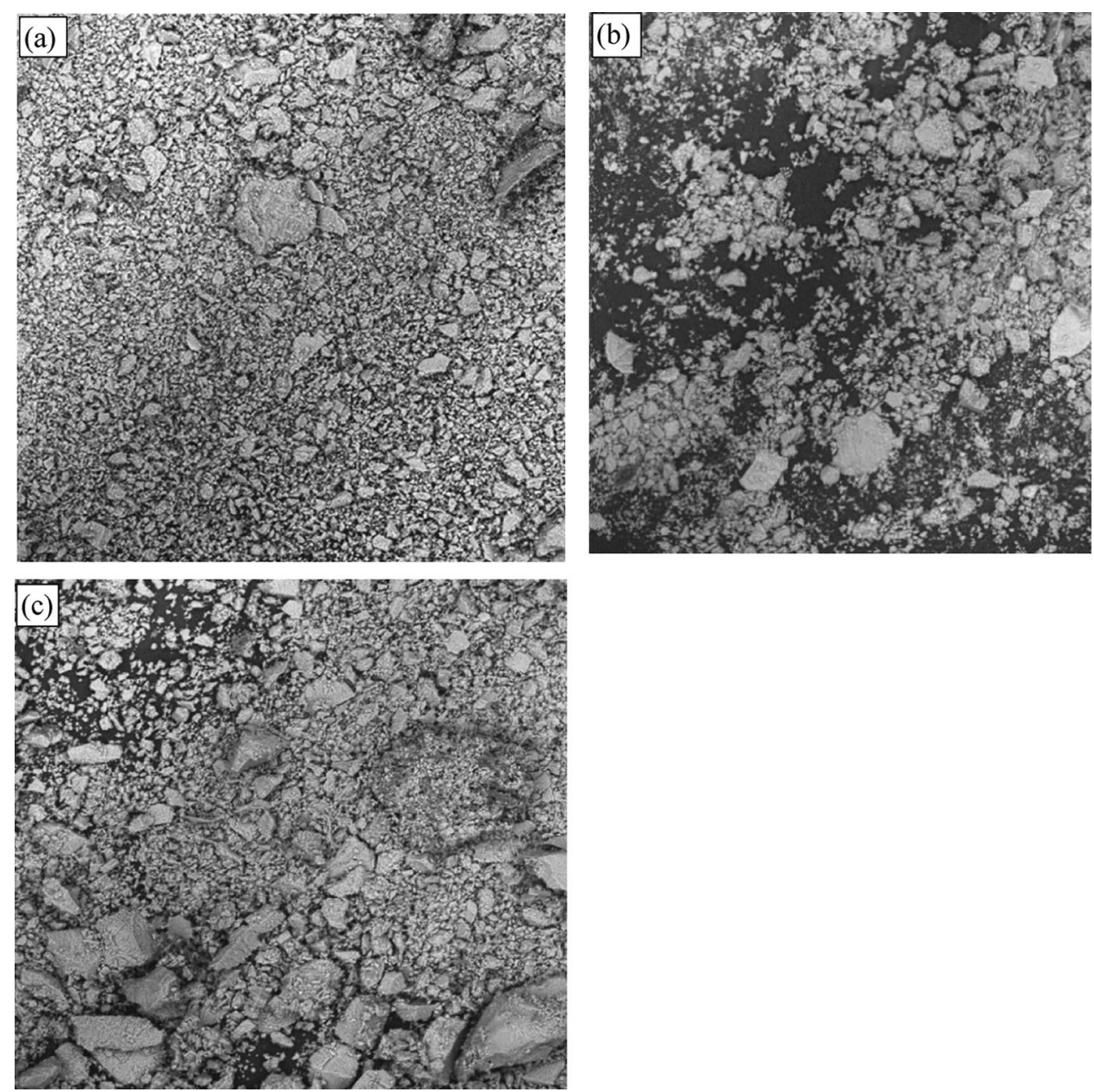

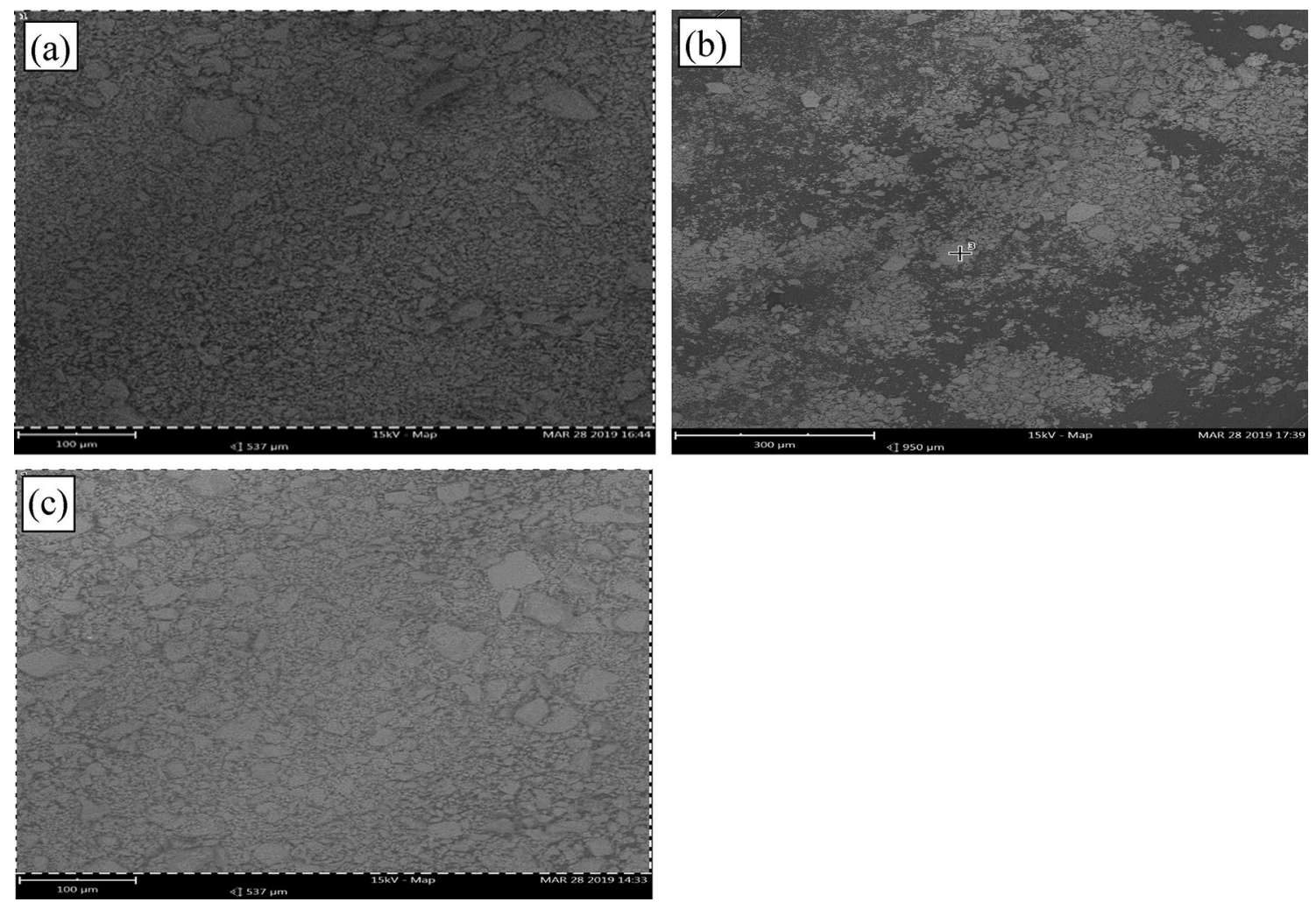

Fig. 2 EDS elemental maps of a chicken eggshell before adsorption, b chicken eggshell after Cd(II) adsorption, c chicken eggshell after $\mathrm{Cr}(\mathrm{VI})$ adsorption

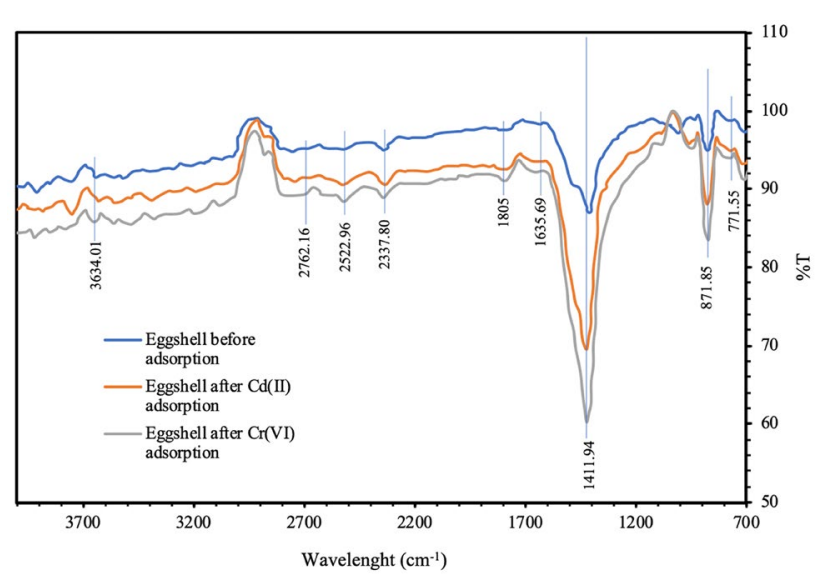

Fig. 3 FTIR spectra of before and after removal of $\mathrm{Cr}(\mathrm{VI})$ and $\mathrm{Cd}(\mathrm{II})$

groups drifted to a lower frequency. The bands of other functional groups also changed to a lower frequency. The results indicate that $\mathrm{Cr}(\mathrm{VI})$ and $\mathrm{Cd}(\mathrm{II})$ ions could have been absorbed by $\mathrm{H}$ and $\mathrm{O}$ atoms of $\mathrm{O}-\mathrm{H}$ and $\mathrm{R}-\mathrm{COOH}$ bonds that altered the frequency of the peaks. The enhancement in the peak found around $1411 \mathrm{~cm}^{-1}$ could indicate $\mathrm{Cd}-\mathrm{O}$ and $\mathrm{Cr}-\mathrm{O}$ stretching for the $\mathrm{Cr}(\mathrm{VI})$ and $\mathrm{Cd}(\mathrm{II})$ absorbed eggshell, respectively. The shifts are traceable to the variations in the counter ions related to carboxylate, $\mathrm{R}-\mathrm{COOH}$ group of amino acids and $\mathrm{OH}$.

\subsection{Adsorption experiment}

\subsubsection{Effect of contact time}

The outcomes presented in Fig. 4 show that the removal rate of adsorbates was swift at the initially (first $30 \mathrm{~min}$ at $\mathrm{pH}$ 4). Upon increasing the contact time to $60 \mathrm{~min}$, there is no substantial change in adsorption capacity for adsorbates. The rapid increase in the adsorption rate within the first 30 min could be attributed to the presence of large number of vacant sites, which are occupied with time. Increasing the contact time even up to 150 min could not engender a meaningful enhancement in the adsorption capacity. Nevertheless, the increase in the removal capacity of $\mathrm{Cr}(\mathrm{VI})$ is higher than that of $\mathrm{Cd}(\mathrm{II})$. For $\mathrm{Cd}(\mathrm{II})$ equilibrium adsorption was attained at $90 \mathrm{~min}$, while the equilibrium was attained at $120 \mathrm{~min}$ for $\mathrm{Cr}(\mathrm{VI})$. At equilibrium time, there is decline in the amount of active sites present and the driving force for adsorption, leading to insignificant or no more adsorption [48]. The quantity of accessible locales turns out to be less, and the adsorbent 

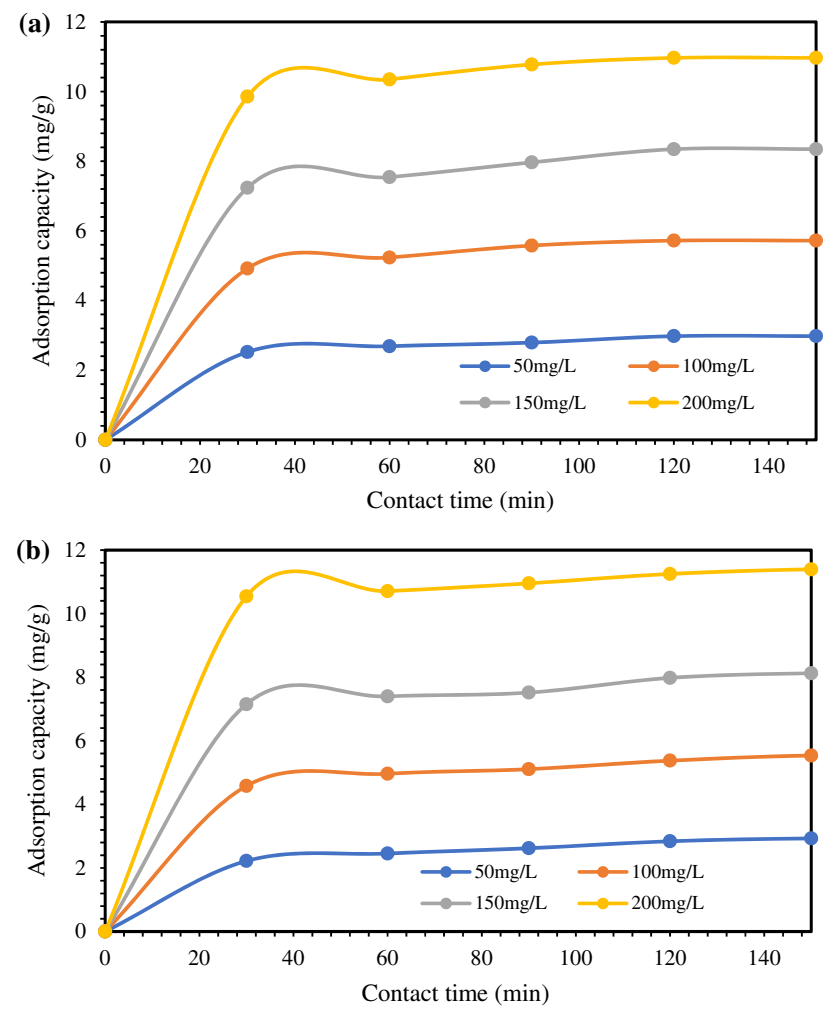

Fig. 4 Effect of contact time on the adsorption of $100 \mathrm{ml}$ a Cd(II) and $\mathbf{b} \mathrm{Cr}(\mathrm{VI})$ ions using $5 \mathrm{~g}$ of eggshell

moves toward becoming swarmed inside the pores, which restricts the movement of the adsorbate [1].

\subsubsection{Effect of adsorbent dose}

Figure 5 gives the influence of the dose of adsorbent on the efficiency of adsorption of $\mathrm{Cr}(\mathrm{VI})$ and $\mathrm{Cd}(\mathrm{II})$. The heavy metal ion removal efficiency was computed by taking the difference in the residual and initial concentrations.

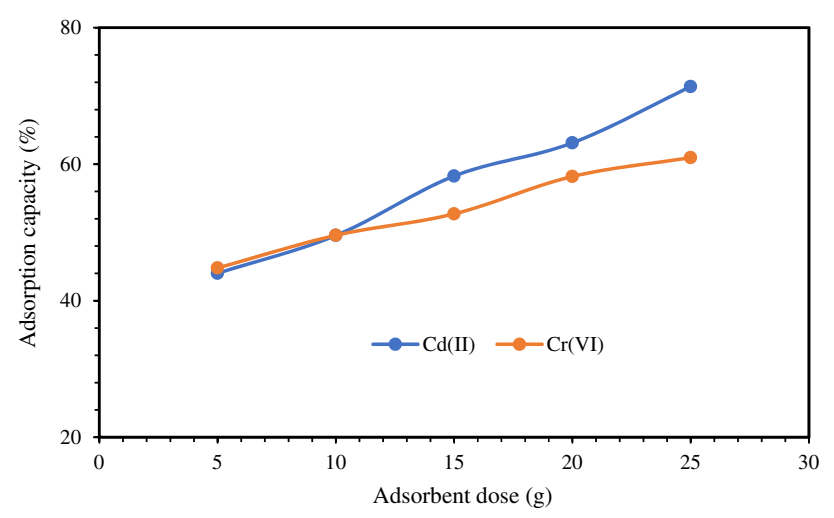

Fig. 5 Influence of adsorbent dose on the removal of $100 \mathrm{ml} \mathrm{a}$ $\mathrm{Cd}(\mathrm{II})$ and $\mathbf{b} \mathrm{Cr}(\mathrm{VI})$ ions using $5 \mathrm{~g}$ of eggshell
The adsorption of $\mathrm{Cd}(\mathrm{II})$ increases from 44.02 to $71.36 \%$, and that of $\mathrm{Cr}(\mathrm{VI})$ was increased from 44.80 to $60.96 \%$ when the dose of adsorbent was varied from 5 to $25 \mathrm{~g}$ for every $100 \mathrm{mg} / \mathrm{L}$ of solution. This shows that the increase in adsorbent dosage significantly favors $\mathrm{Cd}(\mathrm{II})$ than $\mathrm{Cr}(\mathrm{VI})$.

This tendency is likely because of the direct relationship between the adsorbent mass and the number of adsorbent particles. This observation reveals that more adsorption sites and more surface areas are available for heavy metal contact. This also implies that at higher adsorbent to solution volume ratios, superficial adsorption unto the adsorbent (eggshell) surface is swift [13].

\subsubsection{Effect of $\mathrm{pH}$}

Figure 6 illustrates the influence of $\mathrm{pH}$ on the adsorption capacity of eggshell for $\mathrm{Cr}(\mathrm{VI})$ and $\mathrm{Cd}(\mathrm{II})$. Increasing the $\mathrm{pH}$ from 2 to 6 led to a rapid increase in the capacity for adsorption. A further rise in the value of $\mathrm{pH}$ declines the adsorbent performance. The influence $\mathrm{pH}$ can be described by an ion-exchange adsorption technique in which the significance of this work is performed through carbonate groups with cation-exchange characteristics. At low $\mathrm{pH}$ values, heavy metal removal was restricted with a strong dominance of hydrogen ions. This trend is possible because of the difficulty between metal ions and hydrogen on the adsorption site that limits the attraction of the metals. The increase in $\mathrm{pH}$ exposed the presence of carbonate groups in the eggshells to develop the negative charges on the surface of the eggshell particle, attract the cadmium cations and allow the adsorbate adsorption on the adsorbent surface. However, when the equilibrium $\mathrm{pH}$ is reached at 6 , chromium was transformed to chromate anion due to the displacement reaction with $\mathrm{NaOH}$ to generate aqueous $\mathrm{NaCl}$. The competition of chromate and hydroxyl anion on the adsorbent surface which engenders $\mathrm{NaCl}$ formation in the medium declined the adsorption

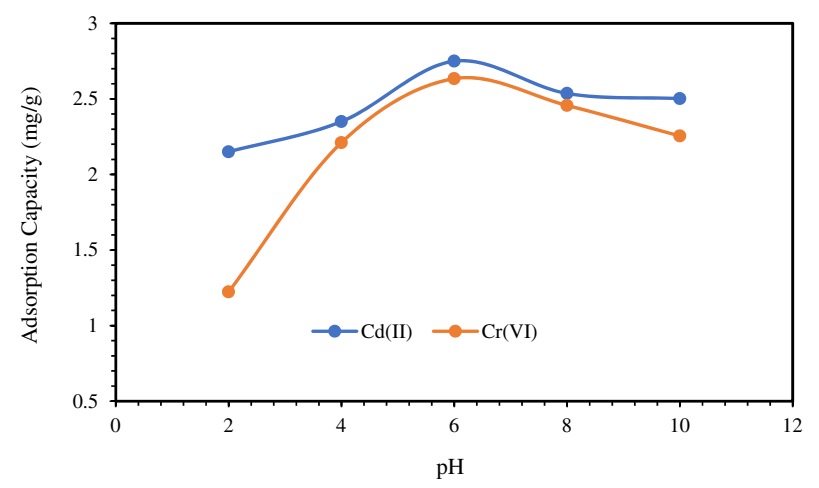

Fig. 6 Effect of $\mathrm{pH}$; on the adsorption of $100 \mathrm{ml} \mathbf{a} \mathrm{Cd}(\mathrm{II})$ and $\mathbf{b} \mathrm{Cr}(\mathrm{Vl})$ ions using $5 \mathrm{~g}$ of eggshell 
of chromium on the eggshell at a pH higher than $6[23$, 29]. The values of the adsorption capacity obtained in this study are quite competitive compared to those of other natural adsorbent reported previously (Table 1).

\subsubsection{Effect of initial metal loading}

Figure 7 gives the influence of the initial loading of $\mathrm{Cd}$ (II) and $\mathrm{Cr}(\mathrm{VI})$ on the removal efficiency of eggshell. The removal of $\mathrm{Cd}$ (II) declined from 85 to $65 \%$, while that of $\mathrm{Cr}(\mathrm{VI})$ reduced from 88.4 to $64.3 \%$ when the initial loading was changed from 50 to $200 \mathrm{mg} / \mathrm{L}$. This observation reveals that adsorption efficiency reduces with increasing initial loading. The reduction in adsorption efficiency could be ascribed to the absence of adequate active site to oblige significantly more metal reachable in the solution [1].

\subsection{Adsorption equilibrium}

Figure 8 presents the Langmuir and Freundlich isotherms for the adsorption of $\mathrm{Cd}(\mathrm{II})$ and $\mathrm{Cr}(\mathrm{VI})$ ion at a pH of 6. The figures give the equilibrium relations between the amount of metal ions on the liquid and solid phase. The isotherms show the information regarding the maximum adsorption capacity of the adsorbent for each adsorbate [1]. The values of $K_{L}$ and $q_{m}$ are estimated from the graph of $C_{e}$ $q_{e}$ versus Ce. (Fig. $\left.7 \mathrm{a}, \mathrm{b}\right)$, and the results are presented in Tables 2 and 3.

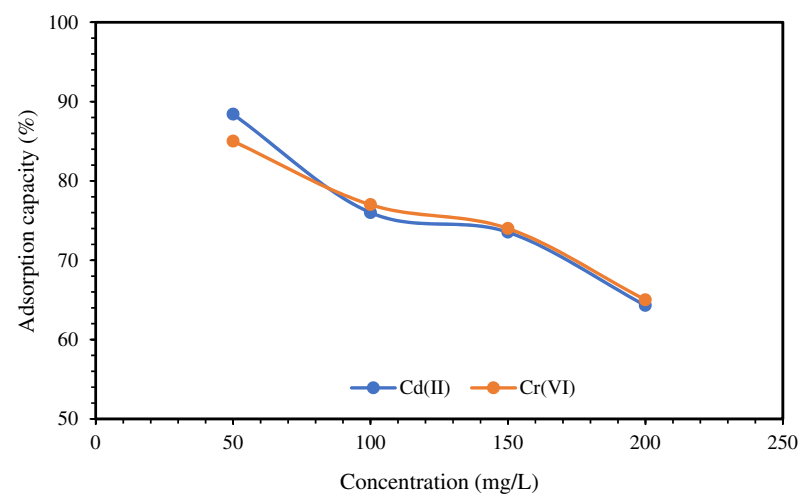

Fig. 7 Effect of initial metal concentration on the adsorption of $100 \mathrm{ml} \mathbf{a} \mathrm{Cd}(\mathrm{II})$ and $\mathbf{b} \mathrm{Cr}(\mathrm{VI})$ ions using $5 \mathrm{~g}$ of eggshell

Langmuir isotherm exhibits essential features obtained from dimensionless constant known as separation factor, or equilibrium parameter $\left(R_{L}\right)$, indicating the adsorption nature [1].

$R_{L}=\frac{1}{1+k_{L} C_{0}}$

The adsorption is favorable when $R_{L}$ is in the range of 0 to 1 . The value of $R_{L}$ more consistent in determining the nature of adsorption. The adsorption is satisfactory if $0<R_{L}<1$ ), unsatisfactory if $R_{L}>1$, irreversible if $R_{L}=0$ or linear if $\mathrm{R}_{\mathrm{L}}=1$ [1]. The $R_{L}$ values for $\mathrm{Cr}(\mathrm{VI})$ and $\mathrm{Cd}(\mathrm{II})$ displayed in Table 4 reveal that the removal of the metal ions onto
Table 1 Comparison of maximum adsorption capacities of Eggshell with other adsorbent

\begin{tabular}{lllcl}
\hline Adsorbent & Adsorbate & $\mathrm{pH}$ & $\mathrm{q}_{0}$ & Ref \\
\hline Eggshell & $\mathrm{Cd}(\mathrm{II})$ & 6 & 3.8 & {$[19]$} \\
Bentonite & $\mathrm{Cd}(\mathrm{II})$ & 5 & 61.4 & {$[35]$} \\
Natural corncob & $\mathrm{Cd}(\mathrm{II})$ & 3.5 & 1.6 & {$[27]$} \\
Spent grain & $\mathrm{Cd}(\mathrm{II})$ & 7 & 17.3 & {$[28]$} \\
Rice husk & $\mathrm{Cd}(\mathrm{II})$ & 9 & 8.58 & {$[25]$} \\
Chitin & $\mathrm{Cd}(\mathrm{II})$ & 7 & 14.7 & {$[12]$} \\
Wood apple shell & $\mathrm{Cd}(\mathrm{II})$ & 5 & 32.1 & {$[45]$} \\
Eggshell & $\mathrm{Cd}(\mathrm{II})$ & 6 & 10.37 & This work \\
Longan seed activated carbon & $\mathrm{Cr}(\mathrm{Vl})$ & 3 & 29.7 & {$[49]$} \\
CTAB modified graphene & $\mathrm{Cr}(\mathrm{VI})$ & 2 & 21.57 & {$[48]$} \\
apple peels activated carbon & $\mathrm{Cr}(\mathrm{VI})$ & 2 & 36.01 & {$[18]$} \\
Surfactant-modified zeolite & $\mathrm{Cr}(\mathrm{VI})$ & 6 & 5.07 & {$[26]$} \\
Hexadecyltrimethylammonium-modified & $\mathrm{Cr}(\mathrm{VI})$ & 3 & 1.06 & {$[40]$} \\
$\quad$ zeolite-rich tuff & $\mathrm{Cr}(\mathrm{Vl})$ & 3 & 3.46 & {$[41]$} \\
Coconut tree sawdust activated carbon & $\mathrm{Cr}(\mathrm{VI})$ & 2 & 0.63 & {$[21]$} \\
Sugarcane bagasse & $\mathrm{Cr}(\mathrm{VI})$ & 6 & 10.71 & This work \\
Eggshell & & &
\end{tabular}



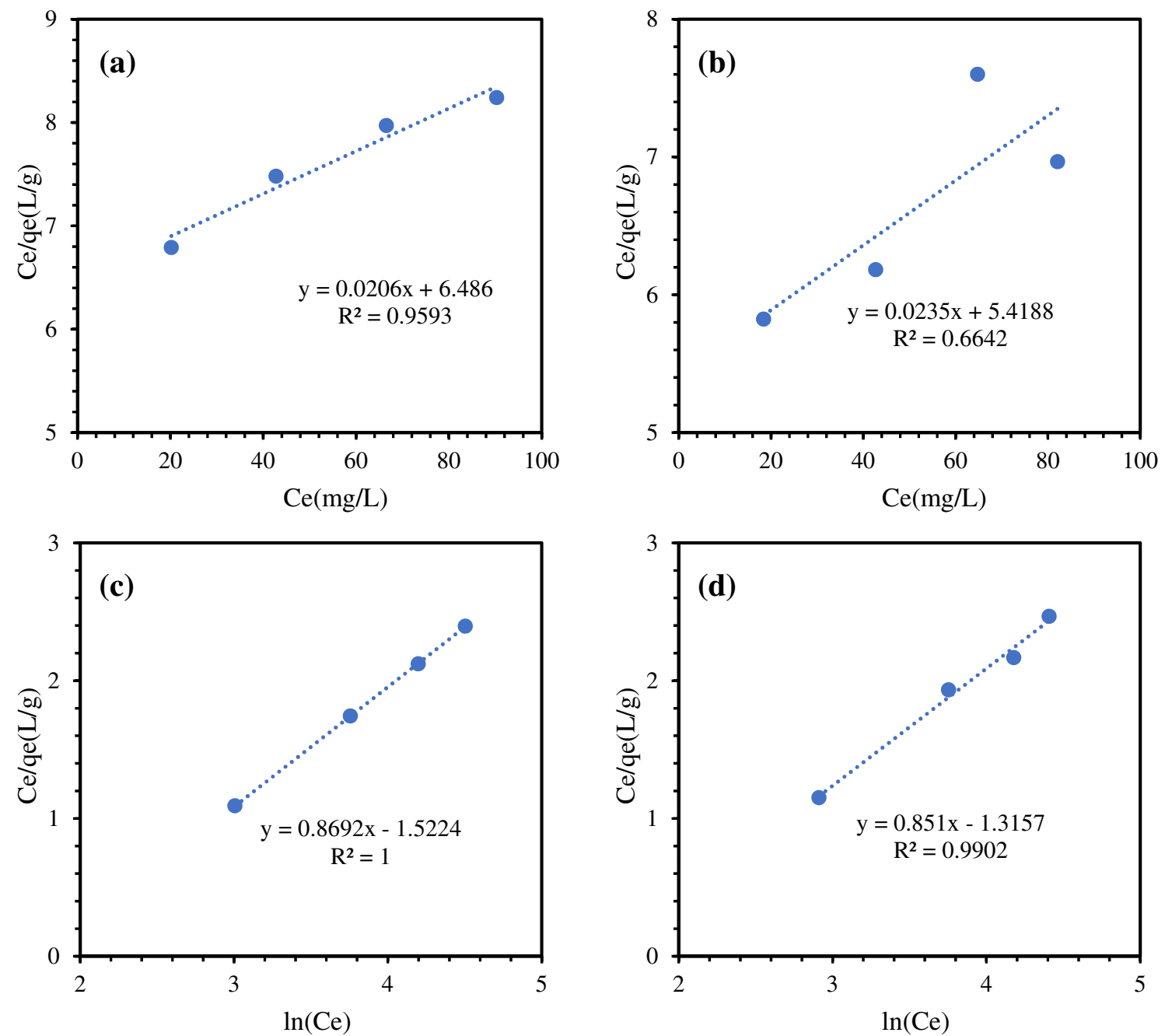

Fig. 8 Langmuir model plot for the adsorption of $\mathbf{a} \mathrm{Cd}(\mathrm{II})$ and $\mathbf{b} \mathrm{Cr}(\mathrm{VI})$ ion, and Freundlich model plot for the adsorption of $\mathbf{c} \mathrm{Cd}(\mathrm{II})$ and $\mathbf{d}$ $\mathrm{Cr}(\mathrm{VI})$ ion using eggshell

Table 2 Freundlich and Langmuir Constants for adsorption of $\mathrm{Cd}(\mathrm{II})$

Table 3 Freundlich and Langmuir Constants for adsorption of $\mathrm{Cr}(\mathrm{VI})$

\begin{tabular}{llllllll}
\hline Adsorbate & \multicolumn{4}{l}{ Freundlich constants } & & \multicolumn{4}{l}{ Langmuir constants } \\
\cline { 2 - 3 } & $n$ & $\mathrm{~K}_{\mathrm{F}}(\mathrm{mg} / \mathrm{g})(\mathrm{L} / \mathrm{mg})^{1 / \mathrm{n}}$ & $\mathrm{R}^{2}$ & & $\mathrm{~K}_{\mathrm{L}}(\mathrm{L} / \mathrm{g})$ & $\mathrm{a}_{\mathrm{L}}(\mathrm{L} / \mathrm{mg})$ & $\mathrm{R}^{2}$ \\
\hline $\mathrm{Cd}(\mathrm{II})$ & 1.1505 & 0.2182 & 1.0 & 0.1541 & 0.00318 & 0.9593 \\
\hline
\end{tabular}

\begin{tabular}{|c|c|c|c|c|c|c|}
\hline \multirow[t]{2}{*}{ Adsorbate } & \multicolumn{3}{|c|}{ Freundlich constants } & \multicolumn{3}{|c|}{ Langmuir constants } \\
\hline & $n$ & $\mathrm{~K}_{\mathrm{F}}(\mathrm{mg} / \mathrm{g})(\mathrm{L} / \mathrm{mg})^{1 / \mathrm{n}}$ & $\mathrm{R}^{2}$ & $\overline{K_{L}(L / g)}$ & $a_{L}(L / m g)$ & $\mathrm{R}^{2}$ \\
\hline $\mathrm{Cr}(\mathrm{VI})$ & 1.1721 & 0.2667 & 0.9902 & 0.1845 & 0.00434 & 0.6642 \\
\hline
\end{tabular}


Table 4 Separation factor, RL values for the $\mathrm{Cd}(\mathrm{II})$ and $\mathrm{Cr}(\mathrm{VI})$ adsorption

\begin{tabular}{lll}
\hline$C_{0}(\mathrm{mg} / \mathrm{L})$ & $\mathrm{R}_{\mathrm{L}}$ \\
\cline { 2 - 3 } & $\mathrm{Cd}(\mathrm{II})$ & $\mathrm{Cr}(\mathrm{VI})$ \\
\hline 50 & 0.115 & 0.098 \\
100 & 0.061 & 0.051 \\
150 & 0.042 & 0.035 \\
200 & 0.031 & 0.026 \\
\hline
\end{tabular}

eggshell powder is favourable. Furthermore, the $R^{2}$ values, which reveal the consistency of the projected outcomes with the observations show that the Freundlich model is more appropriate to describe of the removal of $\mathrm{Cr}(\mathrm{VI})$ and $\mathrm{Cd}(\mathrm{II})$. This result is in agreement with the report of [18, 47] which suggest that Freundlich model is the best for the description of the removal process of $\mathrm{Cd}(\mathrm{II})$ and $\mathrm{Cr}(\mathrm{VI})$.

For the Freundlich isotherm in Fig. $6 c$, d, the values of $K_{F}$ and $n$ attained by removing the metal ions by eggshell can be dobtained (Table 3 ) from the intercept and slope of In $C_{e}$ vs. In $q_{e}$. Since the $\mathrm{R}^{2}$ values for $\mathrm{Cd}(\mathrm{II})$ and $\mathrm{Cr}(\mathrm{VI})$ ions isotherms are higher than 0.9 , the model can satisfactorily describe the connection between the amount of $\mathrm{Cr}(\mathrm{VI})$ and $\mathrm{Cd}(\mathrm{II})$ ions removed by the eggshell and the concentration at equilibrium in wastewater. The adsorption of $\mathrm{Cd}(\mathrm{II})$ and $\mathrm{Cr}(\mathrm{VI})$ with eggshell is favorable since the values of $n$ for adsorbate is in the range of 1-10 [1].

The equilibrium observations for $\mathrm{Cd}$ (II) reveals that the Freundlich and Langmuir model satisfactorily define the adsorption process, but Freundlich model performs better. This observation agrees with the report of [46]. Meanwhile, the Freundlich isotherm model could satisfactorily describe the adsorption of $\mathrm{Cr}(\mathrm{VI})$. This observation does not agree with the reports of $[10,14,31,37]$ which claim that the equilibrium adsorption isotherm for adsorption of $\mathrm{Cd}(\mathrm{II})$ and $\mathrm{Cr}(\mathrm{VI})$ follows Langmuir model rather than Freundlich model.

\subsection{Adsorption kinetics}

Tables 5 and 6 presents the value of $\mathrm{k}_{1}$ and $\mathrm{q}_{\mathrm{t}}$ determined from the graph of In $t / q_{t}$ versus $t$. The suitability of the kinetic model was validated by estimating the $R^{2}$ values (Fig. 9). The estimated $q_{e}$ and experimental $q_{e}$ are close in pseudo-first-order and pseudo-second-order kinetic model for $\mathrm{Cd}(\mathrm{II})$. Meanwhile, for $\mathrm{Cr}(\mathrm{VI})$, the values are closer for the pseudo-second-order kinetic model than pseudofirst-order model at all the initial concentrations, but the pseudo-second-order kinetic model shows a better
Table 5 Kinetic parameters for removal of $\mathrm{Cd}(\mathrm{II})$ using eggshell

\begin{tabular}{lllllll}
\hline $\mathrm{C}_{0}(\mathrm{mg} / \mathrm{L})$ & $\mathrm{q}_{\mathrm{e}, \exp }(\mathrm{mg} / \mathrm{g})$ & \multicolumn{2}{l}{ Pseudo-first order } & \multicolumn{2}{l}{$\begin{array}{l}\text { Pseudo-second } \\
\text { order }\end{array}$} \\
& & $\begin{array}{l}\mathrm{k}_{1}(\mathrm{~g} / \mathrm{mg} \\
\mathrm{min})\end{array}$ & $\mathrm{R}^{2}$ & & $\begin{array}{l}\mathrm{k}_{2}(\mathrm{~L} / \mathrm{mg} \\
\mathrm{min})\end{array}$ & $\mathrm{R}^{2}$ \\
\hline 50 & 2.98 & 0.015 & 1 & 0.078 & 0.997 \\
100 & 5.72 & 0.03 & 0.963 & 0.05 & 0.998 \\
150 & 8.35 & 0.018 & 0.95 & 0.032 & 0.998 \\
200 & 11 & 0.03 & 0.963 & 0.039 & 0.992 \\
\hline
\end{tabular}

Table 6 Kinetic parameters for removal of $\mathrm{Cr}(\mathrm{VI})$ using eggshell

\begin{tabular}{lllllll}
\hline$C_{0}(\mathrm{mg} / \mathrm{L})$ & $\mathrm{q}_{\mathrm{e} \text { exp }}(\mathrm{mg} / \mathrm{g})$ & \multicolumn{2}{l}{ Pseudo-first order } & \multicolumn{2}{l}{$\begin{array}{l}\text { Pseudo-second } \\
\text { order }\end{array}$} \\
& & $\begin{array}{l}\mathrm{k}_{1}(\mathrm{~g} / \mathrm{mg} \\
\mathrm{min})\end{array}$ & $\mathrm{R}^{2}$ & & $\begin{array}{l}\mathrm{k}_{2}(\mathrm{~L} / \mathrm{mg} \\
\mathrm{min})\end{array}$ & $\mathrm{R}^{2}$ \\
\hline 50 & 3.16 & 0.012 & 0973 & 0.025 & 0.986 \\
100 & 6.91 & 0.005 & 0.98 & 0.011 & 0.995 \\
150 & 8.52 & 0.01 & 0.873 & 0.018 & 0.995 \\
200 & 11.8 & 0.01 & 0.873 & 0.021 & 0.998 \\
\hline
\end{tabular}

correlation $\left(R^{2}>0.99\right)$. This observation is because the $R^{2}$ values for the pseudo-second-order model $\left(R^{2}>0.99\right)$ were superior to the $R^{2}$ values of the pseudo-first-order equation for $\mathrm{Cr}(\mathrm{VI})$ ions. These findings suggest that the pseudo-second-order shows a more remarkable correlation in comparison with pseudo-first-order model for $\mathrm{Cd}$ (II) and $\mathrm{Cr}(\mathrm{VI})$. This report agrees with those of $[37,44,46$, 47], which suggest that the pseudo-second-order kinetic expression is the best for the description of the adsorption process of $\mathrm{Cd}(\mathrm{II})$ and $\mathrm{Cr}(\mathrm{VI})$.

To study the diffusion mechanism and the probable rate-controlling step, intraparticle diffusion model was explored. Previous studies revealed that heavy metal adsorption could follow three possible steps, including adsorption, intraparticle diffusion, and external diffusion [16]. The steps could control the adsorption kinetics individually or altogether [36]. External diffusion resistance is negligible if the batch system is well-agitated. Therefore, adsorption and intraparticle diffusion could be the rate-controlling step. The possibility can be studied using Weber-Morris model (intraparticle diffusion model) by plotting of qt versus ${ }^{\mathrm{t} 1 / 2}$, according to the following expression [48]: 
Fig. 9 a pseudo-first order and $\mathbf{b}$ pseudo-second order for Cd(II), c pseudo-first order and $\mathbf{d}$ pseudo-second order for $\mathrm{Cr}(\mathrm{VI})$
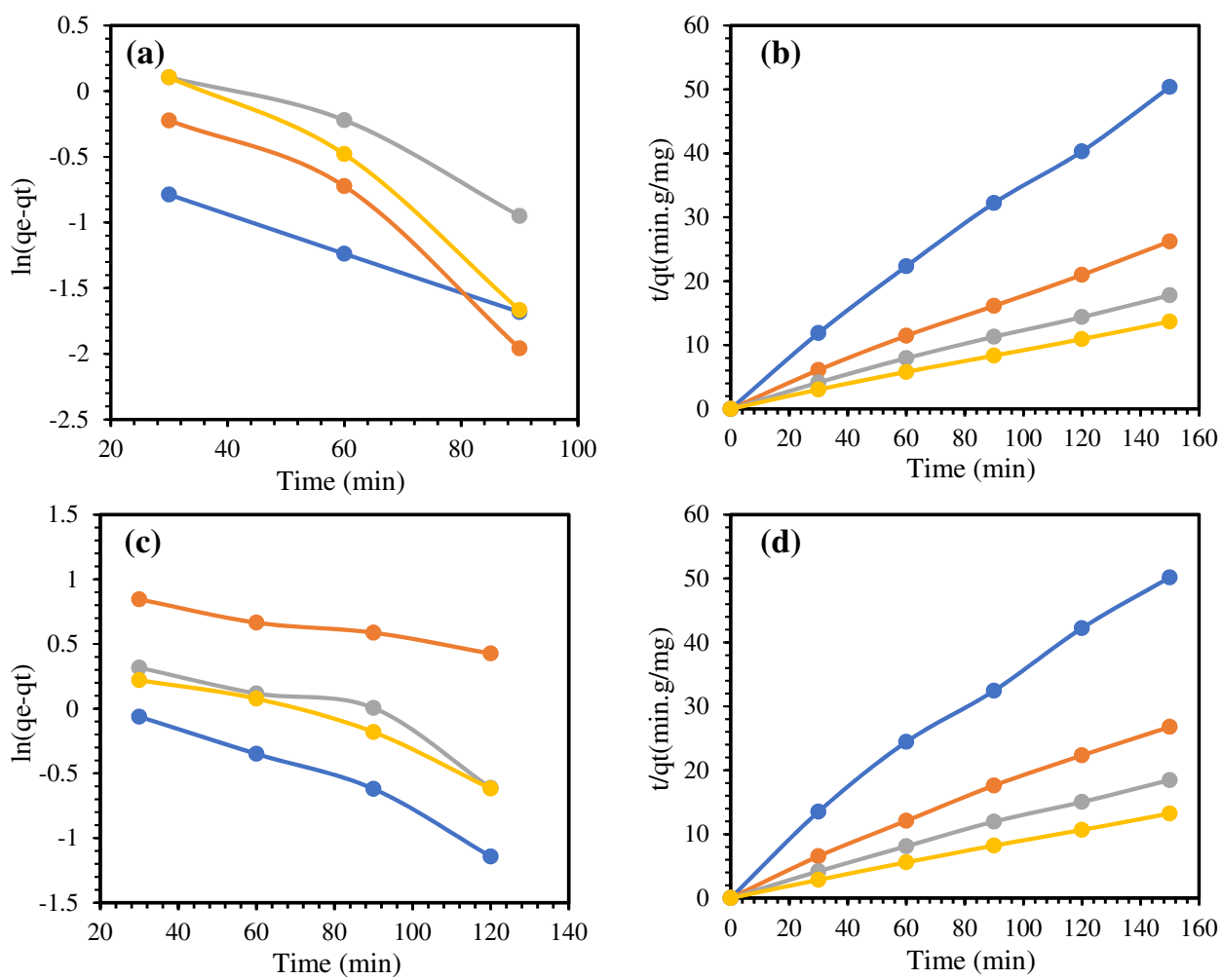

$q_{t}=K_{i d} t^{1 / 2}+C$

where $\mathrm{K}_{\mathrm{id}}$ represents the rate constant for intraparticle diffusion ( $\mathrm{mg} / \mathrm{g} \mathrm{min}^{1 / 2}$ ), and $\mathrm{C}$ represents the intercept are the slope and the intercept of the plot of $q \mathrm{t}$ vs. $t^{1 / 2}$ (Fig. 10). Using this model, intraparticle diffusion is the rate-controlling step if the plot of $q$ t versus $t 1 / 2$ is linear and pass through the origin [48]. Figure 10 and Table 7 reveals that the curves have linear characteristics but the linear plots did not pass through the origin. Therefore, the rate-controlling step is not limited to intraparticle diffusion. The process mechanism is predominant adsorption controlled.

\section{Conclusion}

The potential utilization of eggshell as a adsorbent for the adsorption of $\mathrm{Cr}(\mathrm{VI})$ and $\mathrm{Cd}(\mathrm{II})$ from wastewater was studied, considering various adsorbate concentration, adsorbent dose and pH. Eggshell exhibits carbonyl, 

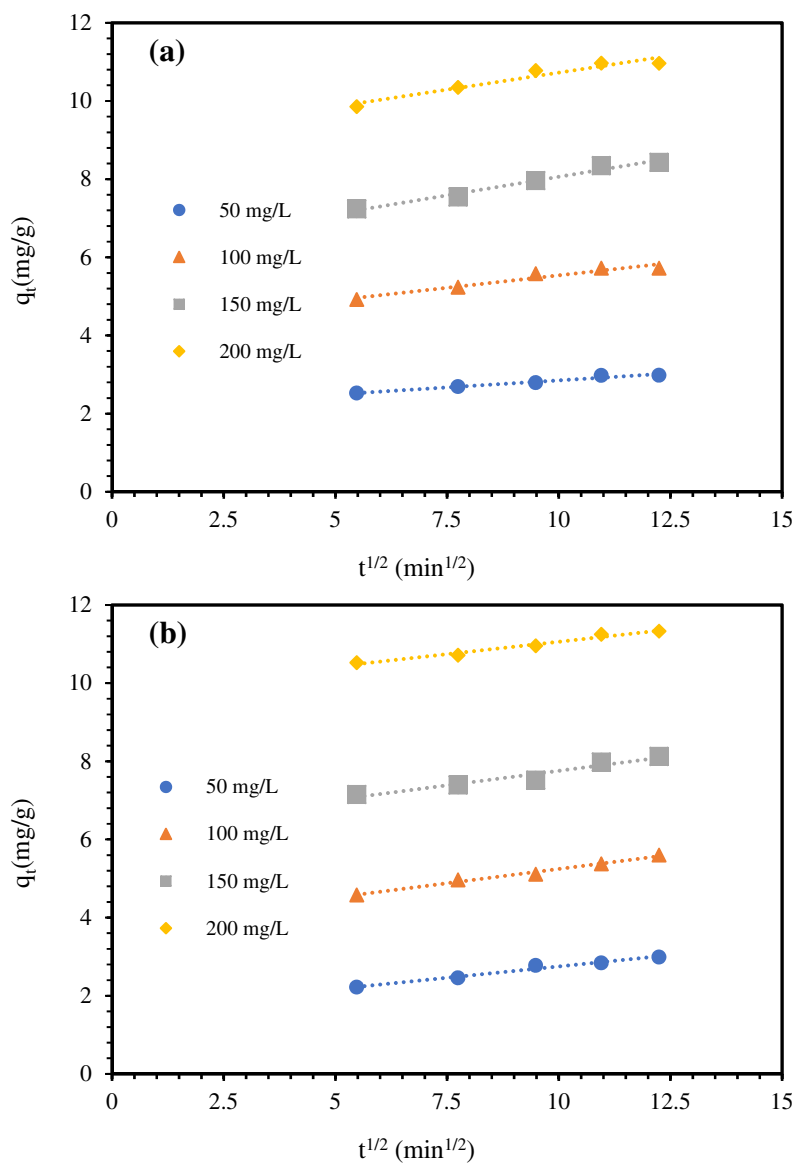

Fig. 10 Intraparticle diffusion plot on $\mathbf{a} \mathrm{Cd}(\mathrm{II})$ and $\mathbf{b} \mathrm{Cr}(\mathrm{VI})$ adsorption by Eggshell carboxylic, hydroxyl functional groups, which plays a substantial role in the adsorption of $\mathrm{Cd}(\mathrm{II})$ and $\mathrm{Cr}(\mathrm{VI})$. The removal of $\mathrm{Cd}(\mathrm{II})$ and $\mathrm{Cr}(\mathrm{VI})$ improved with an increased initial metal presence from 50 to $200 \mathrm{mg} / \mathrm{L}$. The contact time also plays a vital role in the removal of $\mathrm{Cd}(\mathrm{II})$ and $\mathrm{Cr}(\mathrm{VI})$. Increasing the adsorbent dose from 5 to $25 \mathrm{~g}$ leads to an increase in percentage adsorption efficiency of eggshell and increases in the equilibrium adsorption capacity. The best adsorption was attained at the $\mathrm{pH}$ value of 6 for $\mathrm{Cd}(\mathrm{II})$ and $\mathrm{Cr}(\mathrm{VI})$.

The equilibrium observations reveal that Langmuir and Freundlich model could reasonably model the adsorption of $\mathrm{Cd}(\mathrm{II})$. However, the Freundlich model is better, and only the Freundlich model can adequately model the adsorption of $\mathrm{Cr}(\mathrm{VI})$. The best monolayer adsorption capacity of $\mathrm{Cd}(\mathrm{II})$ is $10.967 \mathrm{mg} / \mathrm{g}$ and $11.789 \mathrm{mg} / \mathrm{g}$ for $\mathrm{Cr}(\mathrm{Vl})$ at $200 \mathrm{mg} / \mathrm{L}$, at room temperature. This observation signifies that the adsorption process is adequate, and the observations agree with previous reports on removal of toxic heavy metal ions.

In view of the value of $R^{2}$ and variance between the predicted and the experimental values of $\mathrm{q}_{\mathrm{e}}$. The best model for removal of $\mathrm{Cr}(\mathrm{VI})$ and $\mathrm{Cd}(\mathrm{II})$ from wastewater is pseudo-second-order kinetic. Hence, the eggshell powder is a promising sorbent for adsorption of $\mathrm{Cd}(\mathrm{II})$ and $\mathrm{Cr}(\mathrm{VI})$ from wastewater.
Table 7 Intraparticle diffusion constants at different initial concentrations of $\mathrm{Cd}(\mathrm{II})$ and $\mathrm{Cr}(\mathrm{VI})$

\begin{tabular}{|c|c|c|c|c|c|c|}
\hline \multirow{2}{*}{$\begin{array}{l}\text { Concentration } \\
(\mathrm{mg} / \mathrm{L})\end{array}$} & \multicolumn{3}{|l|}{$\mathrm{Cd}(\mathrm{II})$} & \multicolumn{3}{|l|}{$\mathrm{Cr}(\mathrm{VI})$} \\
\hline & $\begin{array}{l}\mathrm{K}_{\mathrm{id}} \\
\left(\mathrm{mg} / \mathrm{g} \mathrm{min}^{1 / 2}\right)\end{array}$ & $C$ & $\mathrm{R}^{2}$ & $\begin{array}{l}\text { Kid } \\
\left(\mathrm{mg} / \mathrm{g} \mathrm{min}^{1 / 2}\right)\end{array}$ & $C$ & $\mathrm{R}^{2}$ \\
\hline 50 & 0.0719 & 2.1313 & 0.9668 & 0.1158 & 1.5924 & 0.9773 \\
\hline 100 & 0.1273 & 4.2659 & 0.943 & 0.1459 & 3.7859 & 0.9888 \\
\hline 150 & 0.19 & 6.1608 & 0.9787 & 0.1485 & 6.2709 & 0.9415 \\
\hline 200 & 0.1268 & 9.7905 & 0.975 & 0.1268 & 9.7905 & 0.975 \\
\hline
\end{tabular}


Acknowledgements This work was supported by the Deanship of Scientific Research (DSR), King Abdulaziz University, Jeddah. The authors, therefore, gratefully acknowledge DSR technical and financial support.

\section{Compliance with ethical standards}

Conflict of interest The authors declare that there is no conflict of interest.

\section{References}

1. Adebisi GA, Chowdhury ZZ, Alaba PA (2017) Equilibrium, kinetic, and thermodynamic studies of lead ion and zinc ion adsorption from aqueous solution onto activated carbon prepared from palm oil mill effluent. J Clean Prod 148:958-968

2. Agboola O, Agboola O, Popoola P, Sadiku R, Sanni SE, Babatunde DE, Alaba PA, Fayomi SO (2019a) Advanced materials for laser surface cladding: processing, manufacturing, challenges and future prospects. Photoenergy Thin Film Mater, pp 563-615

3. Agboola O, Fayomi OSI, Sadiku R, Popoola P, Alaba PA, Adegbola AT (2020a) Polymers blends for the improvement of nanofiltration membranes in wastewater treatment: a short review. Mater Today Proc

4. Agboola O, Okoli B, Sanni SE, Alaba PA, Popoola P, Sadiku ER, Mubiayi PM, Akinlabi ET, Makhatha ME (2019) Synthesis of activated carbon from olive seeds: investigating the yield, energy efficiency, and dye removal capacity. SN Appl Sci 1(1):85

5. Agboola O, Sadiku R, Popoola P, Sanni SE, Alaba PA, Oyekunle DT, Fasiku VO, Mubiayi MP (2020) Role and characterization of nanobased membranes for environmental applications. Membranes for environmental applications. Springer, Berlin, pp 295-352

6. Ahmad R, Kumar R, Haseeb S (2012) Adsorption of Cu2+ from aqueous solution onto iron oxide coated eggshell powder: Evaluation of equilibrium, isotherms, kinetics, and regeneration capacity. Arab J Chem 5(3):353-359

7. Al-Ghouti MA, Salih NR (2018) Application of eggshell wastes for boron remediation from water. J Mol Liq 256:599-610

8. Alaba PA, Oladoja NA, Sani YM, Ayodele OB, Mohammed IY, Olupinla SF, Daud WMW (2018) Insight into wastewater decontamination using polymeric adsorbents. J Environ Chem Eng 6(2):1651-1672

9. Alaba PA, Sani YM, Olupinla SF, Daud WMW, Mohammed IY, Enweremadu CC, Ayodele OO (2017) Toward N-nitrosamines free water: formation, prevention, and removal. Crit Rev Environ Sci Technol 47(24):2448-2489

10. Baláž M, Bujňáková Z, Baláž P, Zorkovská A, Danková Z, Briančin $\mathrm{J}$ (2015) Adsorption of cadmium (II) on waste biomaterial. J Colloid Interface Sci 454:121-133

11. Banik S, Das K, Islam M, Salimullah M (2014) Recent advancements and challenges in microbial bioremediation of heavy metals contamination. JSM Biotechnol Biomed Eng 2(1):1035

12. Benguella $B$, Benaissa $H$ (2002) Cadmium removal from aqueous solutions by chitin: kinetic and equilibrium studies. Water Res 36(10):2463-2474

13. Campos AFC, de Oliveira HAL, da Silva FN, da Silva FG, Coppola P, Aquino R, Mezzi A, Depeyrot J (2019) Core-shell bimagnetic nanoadsorbents for hexavalent chromium removal from aqueous solutions. J Hazard Mater 362:82-91

14. Cao C-Y, Liang C-H, Yin Y, Du L-Y (2017) Thermal activation of serpentine for adsorption of cadmium. J Hazard Mater 329:222-229
15. Chandrasekaran A, Patra C, Narayanasamy S, Subbiah S (2020) Adsorptive removal of Ciprofloxacin and Amoxicillin from single and binary aqueous systems using acid-activated carbon from Prosopis juliflora. Environ Res, p 109825

16. Deng X, Lü L, Li H, Luo F (2010) The adsorption properties of Pb (II) and Cd (II) on functionalized graphene prepared by electrolysis method. J Hazard Mater 183(1-3):923-930

17. Elabbas S, Mandi L, Berrekhis F, Pons MN, Leclerc JP, Ouazzani N (2016) Removal of $\mathrm{Cr}$ (III) from chrome tanning wastewater by adsorption using two natural carbonaceous materials: Eggshell and powdered marble. J Environ Manage 166:589-595

18. Enniya I, Rghioui L, Jourani A (2018) Adsorption of hexavalent chromium in aqueous solution on activated carbon prepared from apple peels. Sustain Chem Pharm 7:9-16

19. Flores-Cano JV, Leyva-Ramos R, Mendoza-Barron J, GuerreroCoronado RM, Aragón-Piña A, Labrada-Delgado GJ (2013) Sorption mechanism of Cd (II) from water solution onto chicken eggshell. Appl Surf Sci 276:682-690

20. Garcia-Soto M, Camacho EMO (2006) Boron removal by means of adsorption with magnesium oxide. Sep Purif Technol 48(1):36-44

21. Garg UK, Kaur M, Garg V, Sud D (2007) Removal of hexavalent chromium from aqueous solution by agricultural waste biomass. J Hazard Mater 140(1-2):60-68

22. Guru PS, Dash S (2014) Sorption on eggshell waste-a review on ultrastructure, biomineralization and other applications. Adv Coll Interface Sci 209:49-67

23. Jain M, Garg VK, Kadirvelu K (2010) Adsorption of hexavalent chromium from aqueous medium onto carbonaceous adsorbents prepared from waste biomass. J Environ Manage 91(4):949-957

24. Khedr S, Shouman M, Fathy N, Attia A (2014) Effect of physical and chemical activation on the removal of hexavalent chromium ions using palm tree branches. International Scholarly Research Notices 2014

25. Kumar U, Bandyopadhyay M (2006) Sorption of cadmium from aqueous solution using pretreated rice husk. Biores Technol 97(1):104-109

26. Leyva-Ramos R, Jacobo-Azuara A, Diaz-Flores P, Guerrero-Coronado R, Mendoza-Barron J, Berber-Mendoza M (2008) Adsorption of chromium ( $\mathrm{VI}$ ) from an aqueous solution on a surfactantmodified zeolite. Colloids Surf A 330(1):35-41

27. Leyva-Ramos R, Landin-Rodriguez L, Leyva-Ramos S, MedellinCastillo N (2012) Modification of corncob with citric acid to enhance its capacity for adsorbing cadmium (II) from water solution. Chem Eng J 180:113-120

28. Low K, Lee C, Liew S (2000) Sorption of cadmium and lead from aqueous solutions by spent grain. Process Biochem 36(1-2):59-64

29. Maleki A, Hayati B, Naghizadeh M, Joo SW (2015) Adsorption of hexavalent chromium by metal organic frameworks from aqueous solution. J Ind Eng Chem 28:211-216

30. Mittal A, Teotia M, Soni R, Mittal J (2016) Applications of egg shell and egg shell membrane as adsorbents: a review. J Mol Liq 223:376-387

31. Mthombeni NH, Onyango MS, Aoyi O (2015) Adsorption of hexavalent chromium onto magnetic natural zeolite-polymer composite. J Taiwan Inst Chem Eng 50:242-251

32. Naje AS, Ajeel MA, Alaba PA, Chelliapan S (2018) Treatment of textile wastewater using a novel electrocoagulation reactor design. Wastewater Water Qual, pp 111-123.

33. Naje AS, Chelliapan S, Zakaria Z, Ajeel MA, Alaba PA (2017) A review of electrocoagulation technology for the treatment of textile wastewater. Rev Chem Eng 33(3):263-292 
34. Okieimen FE, Okundia EU, Ogbeifun DE (1991) Sorption of cadmium and lead ions on modified groundnut (Arachis hypogea) husks. J Chem Technol Biotechnol 51(1):97-103

35. Orolínovaá Z, Mockovčiaková A, Škvarla J (2010) Sorption of cadmium (II) from aqueous solution by magnetic clay composite. Desalin Water Treatment 24(1-3):284-292

36. Özer D, Dursun G, Özer A (2007) Methylene blue adsorption from aqueous solution by dehydrated peanut hull. J Hazard Mater 144(1-2):171-179

37. Panda L, Das B, Rao D, Mishra B (2011) Application of dolochar in the removal of cadmium and hexavalent chromium ions from aqueous solutions. J Hazard Mater 192(2):822-831

38. Park HJ, Jeong SW, Yang JK, Kim BG, Lee SM (2007) Removal of heavy metals using waste eggshell. J Environ Sci 19(12):1436-1441

39. Patra C, Shahnaz T, Subbiah S, Narayanasamy S (2020) Comparative assessment of raw and acid-activated preparations of novel Pongamia pinnata shells for adsorption of hexavalent chromium from simulated wastewater. Environ Sci Pollut Res, pp 1-16.

40. Salgado-Gómez N, Macedo-Miranda M, Olguín M (2014) Chromium $\mathrm{VI}$ adsorption from sodium chromate and potassium dichromate aqueous systems by hexadecyltrimethylammonium-modified zeolite-rich tuff. Appl Clay Sci 95:197-204

41. Selvi K, Pattabhi S, Kadirvelu K (2001) Removal of Cr (VI) from aqueous solution by adsorption onto activated carbon. Biores Technol 80(1):87-89

42. Shahnaz T, Patra C, Sharma V, Selvaraju N (2020) A comparative study of raw, acid-modified and EDTA-complexed Acacia auriculiformis biomass for the removal of hexavalent chromium. Chem Ecol 36(4):360-381
43. Shahnaz T, Sharma V, Subbiah S, Narayanasamy S (2020) Multivariate optimisation of $\mathrm{Cr}$ (VI), Co (III) and Cu (II) adsorption onto nanobentonite incorporated nanocellulose/chitosan aerogel using response surface methodology. J Water Process Eng 36:101283

44. Simões M, Baranton S, Coutanceau C (2011) Enhancement of catalytic properties for glycerol electrooxidation on $\mathrm{Pt}$ and $\mathrm{Pd}$ nanoparticles induced by Bi surface modification. Appl Catal B 110:40-49

45. Suresh C, Reddy D, Harinath Y, Naik BR, Seshaiah K, Reddy AVR (2014) Development of wood apple shell (Feronia acidissima) powder biosorbent and its application for the removal of Cd (II) from aqueous solution. Sci World J, 2014

46. Tizo MS, Blanco LAV, Cagas ACQ, Cruz BRBD, Encoy JC, Gunting JV, Arazo RO, Mabayo VIF (2018) Efficiency of calcium carbonate from eggshells as an adsorbent for cadmium removal in aqueous solution. Sustain Environ Res 28(6):326-332

47. Vakili M, Deng S, Li T, Wang W, Wang W, Yu G (2018) Novel crosslinked chitosan for enhanced adsorption of hexavalent chromium in acidic solution. Chem Eng J 347:782-790

48. Wu Y, Luo H, Wang H, Wang C, Zhang J, Zhang Z (2013) Adsorption of hexavalent chromium from aqueous solutions by graphene modified with cetyltrimethylammonium bromide. J Colloid Interface Sci 394:183-191

49. Yang J, Yu M, Chen W (2015) Adsorption of hexavalent chromium from aqueous solution by activated carbon prepared from longan seed: Kinetics, equilibrium and thermodynamics. J Ind Eng Chem 21:414-422

Publisher's Note Springer Nature remains neutral with regard to jurisdictional claims in published maps and institutional affiliations. 